CEPAL REVIEW 82 . APRIL 2004

\title{
Industrial competitiveness in Brazil ten years after economic liberalization
}

J oão Carlos Ferraz

Director, Division of Production Productivity and Management

ECLAC

- jcferraz@eclac.cl

David Kupfer

Institute of Economics of the

Federal

University of Rio de J aneiro

(UFRJ ), Brazil

- kupfer@ic.ufrj.br

Mariana lootty

University of Rio de J aneiro (UFRJ ), Brazil

- miootty@ie.ufrj.br
João Carlos Ferraz, David Kupfer and Mariana Iootty

$\Gamma$ his article examines the nature and extent of the changes in B razilian industry after ten years of economic liberalization. The article demonstrates that most structural features of Brazilian industry remain unchanged except in the management of production processes and in the ownership structure of firms, as rationalization and inward internationalization became generalized processes. Brazil may face a development paradox in the years to come. History suggests that local capital and innovation capabilities have been outstanding features of countries successful in achieving sustained economic development. If internationalization of ownership is to remain and local innovation capabilities are to be pursued, then Brazilian private and public policy makers must depart from established policy practices and seek new ways of regulating and inducing firms towards local value creation. 
I

\section{Introduction}

In 1996, we published, in CEPAL Review and in a book with Lia Haguenauer, ${ }^{1}$ an in-depth analysis of the competitiveness of Brazilian industry (Ferraz, Kupfer and Haguenauer, 1996a and 1996b). The present article $^{2}$ updates that analysis by examining the nature and extent of changes in Brazilian industry between 1990 and 2002, a period of significant institutional and economic transformation. Economic liberalization became the central feature of the national regime of incentives and regulations and, after decades of high inflation, price stabilization was achieved, becoming thereafter a major target of macroeconomic policies. But, during the same period, low rates of growth, with frequent annual oscillations, prevailed.

Elsewhere, in most developed and developing countries, economic liberalization also became the prevalent regime of incentives and regulations, while international flows of capital, goods and services and the diffusion of information technologies were accelerating. In Latin America, within the context of the North American Free Trade Agreement (NAFTA), Mexico became a specialized supplier to the United States in the assembly of electronic goods and other labour-intensive industries. Chile modified its industrial matrix, shifting towards exploiting and transforming its natural resource base to generate products for export, supported by sophisticated logistics. Argentina changed its strategy several times; for some time it seemed that the country would constitute an important specialized industrial base for the Mercosur market, but the negative consequences of the Argentine convertibility plan resulted in the dismantling of a significant portion of its industrial base.

\footnotetext{
1 This article is dedicated to Lia Haguenauer. We will always miss her companionship, professionalism and personal integrity. Our writings will never again be so sharp and clear.

2 Sectoral information is derived from "Estudo da Competitividade de Cadeias Integradas no Brasil" (www.mdic.gov.br), a research project contracted by the Brazilian government to the State University at Campinas (UNICAMP) and coordinated by Luciano Coutinho, Mariano Laplane, David Kupfer and Elizabeth Farina. We are in debt with them and also with Achyles Barcelos da Costa, Fábio Erber, Fernando Sarti, Germano Mendes de Paula, José Rubens Dória Porto, Márcia Azanha Ferraz Dias de Moraes,
}

What happened in Brazil? To what extent did institutional reform induce changes in industry? Did investment rates increase, incorporating new activities? Which ones ceased to exist? Are firms relying on those capabilities - for example in the field of innovation that are widely known as conforming the basis for sustained or expanded market shares?

It was these questions which guided us in this article. In section II we will update the 1996 discussion on patterns of competition and competitiveness. Section III provides an account of the most important institutional changes and an overview of the evolution of industry between 1990 and 2002. Sections IV to VII are focused on the analysis of competitiveness of four industrial sectors: commodities, durable goods, traditional industries and innovation carrier industries. Finally, section VIII gives an overall balance, indicating the common features and differences between these sectors.

Our 1996 contribution was based on extensive research carried out in the early 1990s (Coutinho and Ferraz, 1994). Since then, no other comprehensive work has been undertaken which would allow a systematic update on industrial competitiveness. The most important research has been the "Estudo da Competitividade de Cadeias Integradas no Brasil" made by the Ministry of Development, Industry and External Trade (MDIC) (www.mdic.gov.br), covering 20 industrial sectors, which constituted the informational basis for this article.
Marcos Fava Neves, Maria Graça Derengowsky Fonseca, Matheus
Kfouri Marino, Mauro Thury de Vieira Sá, Rafael Oliva, Roberto
Vermulm and Victor Prochnik for their high-quality sectoral analy-
ses. The National Council for Scientific and Technological Research
(CNPq) and the Carlos Filho de Amparo Research Foundation of
the state of Rio de Janeiro (FAPERJ) provided support for the activ-
ities carried out by the authors in the Industry and Competitiveness
Research Group of the Institute of Economics of the Federal
University of Rio de Janeiro (UFRJ). This article is based on a
report produced for the Institute of Developing Economies, Japan
(Hamaguchi, 2003). 


\section{II}

\section{Competitiveness and patterns of competition}

In this article, competitive firms are considered to be those capable of formulating and implementing strategies leading to sustained or expanded market position in the segment of industry where they operate. To be competitive, a firm's strategies, capabilities and performance must be coherent with the pattern of competition (PoC) prevalent in the activity in which it operates. Patterns of competition are defined as the collection of competitive driving factors required for success in an industry. As competitiveness is defined at the firm level, it is possible to consider, by aggregation, that a sector is competitive if a large proportion of sectoral production value originates from competitive firms at a given moment of time.

Competitiveness must be viewed as a dynamic concept for two reasons. Firstly, it is associated with previously accumulated capabilities of firms. Thus, present capacity results from past strategic decisions on where economic resources should be allocated. Revealed market position or productive performance indicate whether past strategies and capabilities were adequate or not. In this sense, present capabilities or market position do not necessarily ensure future competitiveness. Secondly, important competitive driving factors conforming the $\mathrm{PoC}$ may change due to strategies pursued by innovative firms. Thus competitiveness must be evaluated against the expected, not necessarily the current, pattern of competition at a given moment of time.

Given the large number of possible factors intervening in the PoC, it is necessary to organize them according to some type of criterion. A simple and workable criterion is one in which the factors are organized according to the capacity of a firm to influence their direction and evolution.

Some key factors (internal factors) lie within the boundaries of the firm, where it has complete control. Others (structural factors) are industry-specific and have an equal level of importance for all firms operating in similar market segments. In general, individual firms have only limited and indirect control over structural factors. Finally, there is a collection of drivers (macro factors) which are associated with generic framework conditions surrounding a firm and are beyond its capacity to exert direct influence. Thus, a competitive process has a systemic character, determined not only by the individual firm's efforts, but also by the nature of the industry in which it operates and by economic and institutional aspects.

Sectoral analyses of competition are usually based on structural or behavioural taxonomies. In this article, drawing on the classical works of Steindl, Labini, Scherer, Porter and Pavitt, we propose the existence of four industrial groups - commodity industries; durable goods industries; traditional industries and innovation carrier industries, each comprising industrial sectors possessing similar competitive drivers at the firm and structural levels.

Firms can be successful by offering: i) cost advantages, ii) product differentiation, iii) responsiveness, or iv) technologically sophisticated products. Very few firms can achieve excellence simultaneously in every source of competitive advantage. Competitive firms are those that focus on and develop coherent strategies, capabilities and performance in the factors making up the dominant pattern of competition in the specific industry in which they operate.

Cost competition prevails in the commodity sector. Products are intrinsically undifferentiated, and competitive firms are those capable of achieving the lowest unit costs and the highest production volumes possible, as well as having control over access to inputs and efficient logistics systems, thus reducing input and distribution costs.

Product differentiation is important in the durable goods industries. Most advanced firms try to concentrate their capabilities in design and marketing functions, while production may be extensively sub-contracted. The mobilization and supervision of partners is an essential source of competitive advantage.

Responsiveness is a priority for traditional industries. Firms target market niches aiming at specific consumers, stratified by income, age, etc. Business capacity requirements ${ }^{3}$ are less strict than in other industrial groups, but management and supervisory skills are vital for success.

3 Understood as the overall set of skills, technical knowledge, capabilities and experience of the firm. 
Innovation carriers operate in specific market segments. These firms must have strong technological capabilities and access to updated science and technology laboratories.

\section{III \\ Institutional change and industrial performance}

\section{Economic liberalization}

Economic liberalization, acceleration of trade and cross-border capital flows and the diffusion of information technologies delineated the international context of the 1990s. In Brazil, industry faced two consecutive local competitive shocks - economic liberalization and monetary stabilization. Reforms were aimed at: i) economic deregulation, including the end of price control mechanisms for goods and services and the elimination of protected markets and other regulatory constraints on foreign investment; ii) liberalization of the external sector, including the reduction of trade tariffs and non-tariff barriers and deregulation of the capital account, and iii) privatization of manufacturing industries and public utility services.

Macroeconomic changes were equally important. They were closely associated with the monetary reform implemented under the Plano Real in 1994 and with the subsequent return of capital inflows due to increasing international liquidity and higher local interest rates when compared to other national markets. The Plano Real successfully reduced the inflationary spiral, ${ }^{4}$ resulting in the short term in growth of real wages. That, associated with the resurgence of credit lines for consumption, implied significant increases in aggregate demand. The return of capital inflows - direct investment rose from US\$ 600 million in 1993 to US\$ 29.1 billion in 1998 - was very important for financing current account deficits, mergers and acquisitions and capital investment. Overvaluation of the national currency followed, and it was pushed even further by a set of specific policies defined by the Central Bank between 1994 and 1999.

\footnotetext{
4 Inflation rates went down from more than $1,000 \%$ in 1993 to $20 \%$ in 1995 and $5 \%$ in 1997.
}

The appreciation in the exchange rate and the high interest rates, together with low tariffs and lower barriers to the entry of foreign firms, imposed a new competitive environment on industry. The immediate result was a rapid deterioration in the trade balance. Foreign capital inflows financed trade deficits but, at the same time, the vulnerability of the country's external accounts increased to levels not compatible with macroeconomic stability. Consequently, the negative impacts of external financial dependence were revealed not only in the weak growth of expansionrelated investments, but also in insufficient GDP growth during the 1990s.

\section{Industrial performance}

\section{a) The same structure of production, but with many fewer workers}

The share of Brazilian industry in the economy did not change throughout the 1990s (Rocha and Kupfer, 2002). Among the different industrial groups (table 1), industrial commodities, durable goods and food and beverages showed a better performance due to the income effect generated by the Plano Real (in the case of durable goods and food and beverages) and/or better terms of trade and export performance (industrial commodities and durable goods). The performance of the innovation carriers was notably good around 1995, as a result of better prospects created by the success of the Plano Real, but this was followed by a return of slow growth, as imports expanded significantly and expectations of a better future were not fulfilled. 
TABLE 1

Brazil: Output in different industries, selected years $(1991=100)$

\begin{tabular}{lrrrr}
\hline & 1991 & 1995 & 1998 & 2000 \\
\hline Industrial commodities & 100.0 & 109.6 & 126.8 & 138.2 \\
Agriculture commodities & 100.0 & 97.2 & 101.2 & 98.9 \\
Traditional industry, & & & & \\
except food and beverages & 100.0 & 104.8 & 101.3 & 104.3 \\
Food and beverages & 100.0 & 121.6 & 128.9 & 130.5 \\
Innovation carriers & 100.0 & 120.0 & 105.6 & 108.2 \\
Durable goods & 100.0 & 147.6 & 133.9 & 148.6 \\
Manufacturing & 100.0 & 113.4 & 117.4 & 124.2 \\
\hline
\end{tabular}

Source: Monthly Industrial Survey of the Brazilian Institute of Geography and Statistics (IBGE).

FIGURE 1

Output and employment in Brazilian manufacturing industry, 1985-1999

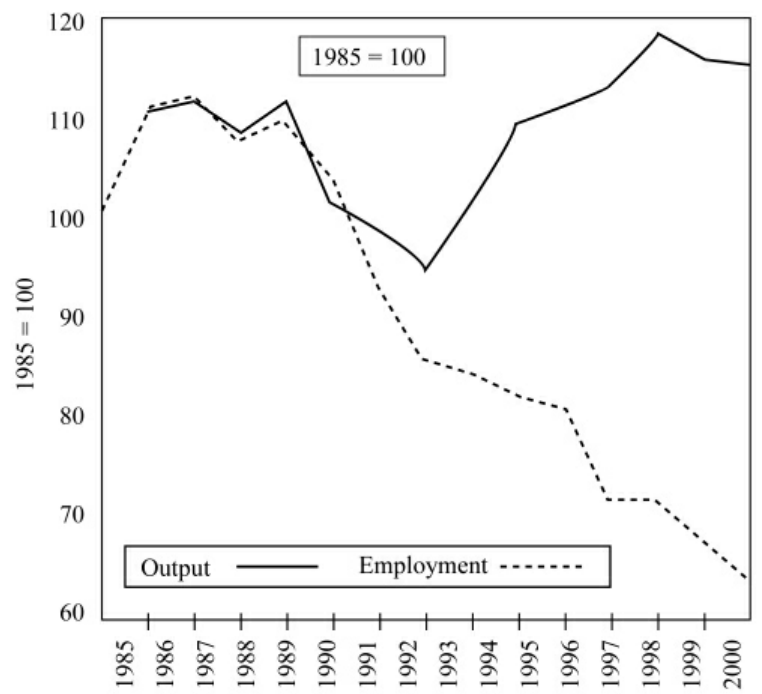

Source: Monthly Industrial Survey and Monthly Employment Survey of the Brazilian Institute of Geography and Statistics (IBGE).

During the 1980s, employment levels fluctuated, but closely followed the erratic evolution of production. However, as shown in figure 1, since the early 1990s, the growth rates of production and employment started to diverge, particularly after 1993. That was a very important change of trajectory, resulting in the doubling of the output-to-labour ratio and higher production efficiency between 1990 and 1999. ${ }^{5}$

\footnotetext{
5 Most available evidence in Brazil is based on series of production value, not on (ideal) series of value added.
}

Many economists identify the beginning of the 1990 s as the break point in the relation between production and employment. For Gonzaga (1996), Amadeo and Soares (1996) and Bonelli (1996), this increasing divergence indicates significant technological change in the economy in terms of production processes and/or organization. This explanation places emphasis on intra- and inter-firm transformations, due to stabilization, trade liberalization and economic deregulation that defined new efficiency parameters for the strategic behaviour of corporations. In reality, as the analysis ahead will show, in most sectors a large proportion of firms did indeed go through a significant modernization process, strongly biased towards cost rationalization. This rationalization included the adoption of improved organizational techniques; the introduction of information technologies and equipment in administration and production; changes in the product portfolio in the direction of greater specialization; subcontracting, de-verticalization, and increased use of imported components. These changes directly implied a lower demand for industrial employment, for the same level of production. It is an open question whether employment rates will ever catch up with past losses.

\section{b) Unchanged trade specialization}

Foreign trade expanded significantly during the 1990s, from US\$ 50 billion in 1990 to US\$ 107 billion in 2002. Between 1990 and 1993 trade levels and the trade balance remained unchanged, suggesting that, per se, tariff reform had only a minor impact on the international insertion of industry. After stabilization cum currency overvaluation and further tariff reductions, foreign trade expanded steadily up to 1997, especially in the case of imports. Thus, while exports rose at a moderate rate, imports trebled between 1990 and 1997. As a result, the trade balance deteriorated and, after 14 years of surpluses, in 1997 the trade deficit reached US\$ 8.2 billion. Regardless of this expansion, however, Brazil's share in world trade has declined from $1.4 \%$ in the mid-1980s to $0.75 \%$ in 2001.

The 1997 Asian crisis triggered off a period of uncertainty in Brazil. International liquidity and trade receded and external vulnerability increased, leading to an exchange crisis that resulted in the depreciation of the Real and the introduction of a floating system in January 1999. From then onwards imports declined, but never below US\$ 40 billion, while exports increased steadily, resulting in trade surpluses in 2001 
and 2002. Concurrently with the expansion of total Brazilian foreign trade, the ratios of exports and imports to domestic production in manufacturing increased steadily. Thus, between 1990 and 2001 the export ratio increased from $8.0 \%$ to $14.9 \%$ while the import ratio trebled, from $4.3 \%$ to $14.8 \%$.
Figure 2 shows the imports and exports of four industrial groups, reflecting the above-mentioned substantial expansion of Brazilian foreign trade and, most important, the existence of sharp differences in the nature of Brazilian imports and exports. ${ }^{6}$

FIGURE 2

Brazil: Foreign trade, by industrial groups, 1989-2002

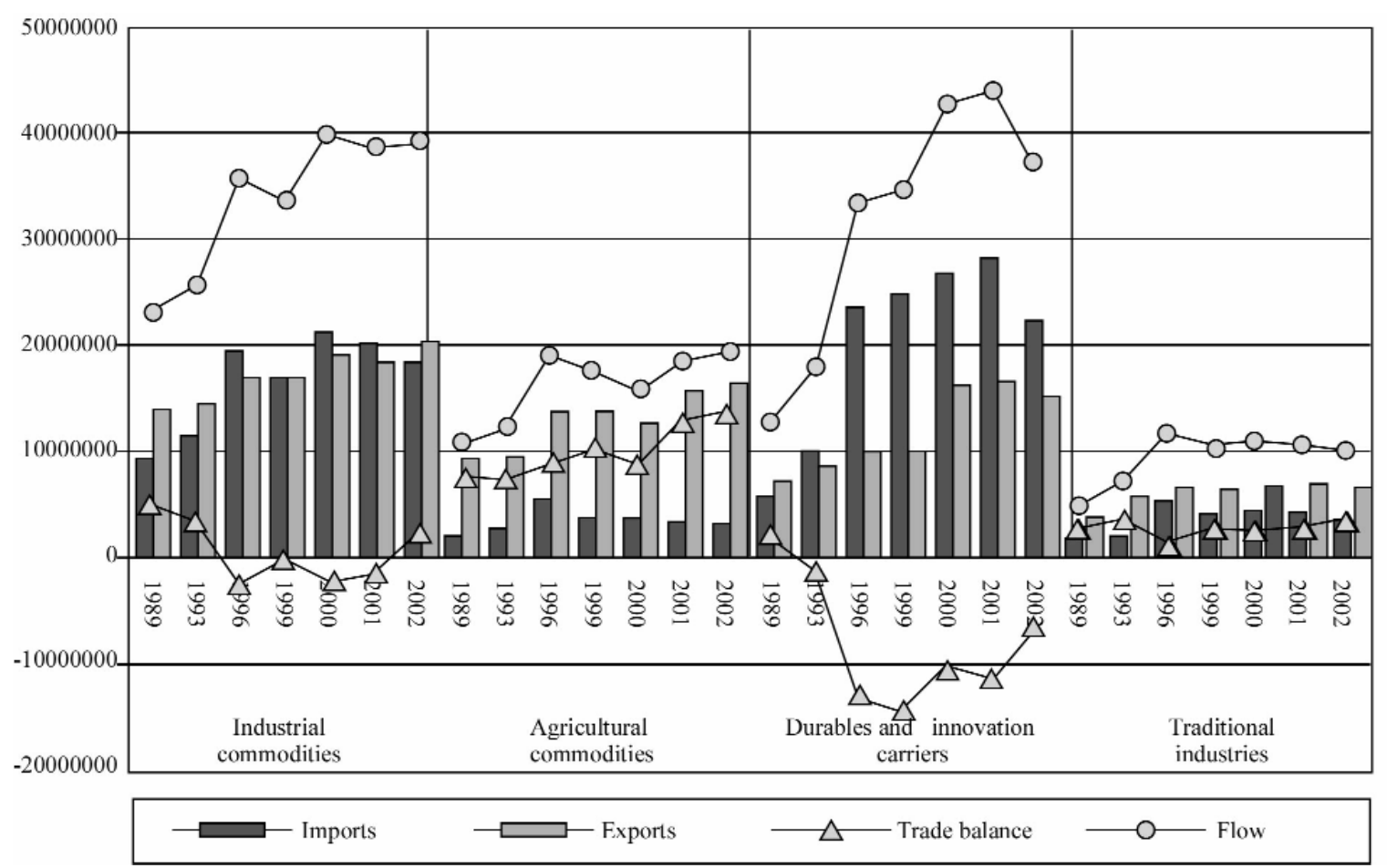

Source: GIC-IE data bank of the Federal University of Rio de Janeiro, based on information from Alice Data Bank.

Firstly, industrial commodities, together with durables and products of innovation carriers, were responsible for $72 \%$ of the US\$ 107 billion total trade in 2002. Secondly, in industrial commodities, trade has been expanding steadily but imports and exports are quite balanced. Contrary to what might be expected, imports of industrial commodities are quite large, especially of chemicals. Thirdly, the pattern of foreign trade in durables and products of innovation carriers is quite different. Most Brazilian trade deficits are to be found in these industrial groups. Between 1996 and 2001, annual deficits remained above US\$ 10 billion. Imports increased steadily, receding only in 2002, concurrently with the acceleration of devaluation of the
Real. Exports reacted positively only after 2000. Fourthly, agricultural commodities are responsible for an important trade surplus, reaching US 20 billion in 2002; exports have been increasing steadily while imports are not significant. Finally, trade flows in the traditional industrial group were relatively stable, at around US\$ 10 billion for most of the decade. In short, foreign trade expanded substantially but the nature of the international insertion of Brazilian industry remained unchanged

\footnotetext{
6 Commodities were divided into industrial and agricultural, while durables and innovation carriers were merged together, due to statistical constraints.
} 


\section{c) Ownership change, stagnation of capital and $R \& D$ investment}

Unlike what occurred in the structure of production, changes in the ownership structure of industry were very pronounced. As shown in table 2, privatization and mergers and acquisitions amounted to US\$ 128 billion between 1990 and 1999. As might be expected, the value per transaction in privatization was much higher than in mergers and acquisitions. The first phase of privatization (1991-1995) involved steelworks, mining and petrochemicals. In the second half of the 1990s electrical power, financial services and telecommunications were privatized. This last sector alone was responsible for US\$ 30 billion in government revenue. Foreign investors were responsible for $76.9 \%$ of the privatization operations and $71.4 \%$ of the mergers and acquisitions.

According to Rocha and Kupfer (2002), among the 300 largest corporations in Brazil, State-owned firms reduced their market share (sales revenue) from $44.6 \%$ in 1991 to $24.3 \%$ in 1999 ; multinationals expanded from $14.8 \%$ to $36.4 \%$, while local capital maintained its position. The authors suggest that ownership change among leading firms occurred in two phases. Between 1991 and 1996, the share of Stateowned firms was transferred to private firms, regard- less of their nationality, as a result of privatization of industrial firms. Between 1996 and 1999 revenue was transferred from national firms (State or privately owned) to multinational firms.

Asset acquisition and transfers reshaped the country's ownership landscape but did not lead to further increases in capital investment. In Brazil, the 1990s was marked by only a modest expansion of gross fixed capital. According to Bielschowsky (1998), the share of industrial investment as a proportion of GDP amounted to $2.2 \%$ in the period from 1988 to 1993 , compared with $4.5 \%$ during the 1970 s. Between 1995 and 1997 investment rates increased to $3.2 \%$, mostly associated with localized equipment renovation.

In fact, as shown in table 3, out of an universe of 72,000 industrial firms, with total sales of R $\$ 582$ billion in 2000, 19,000 firms spent R\$ 22 billion (or 3.8\% of sales revenue) on activities associated with modernization and innovation, ranging from training to R\&D. Of these 19,000, 15,500 firms focused their expenditure on machinery acquisition. A smaller group of firms (10\% of total industrial firms) invested $0.64 \%$ of sales in R\&D activities, but within this select group there were large differences: the bigger the firm, the greater its commitment to R\&D.

TABLE 2

Brazil: Privatization, mergers and acquisitions, 1990-1999

(Value in millions of dollars)

\begin{tabular}{|c|c|c|c|c|c|c|c|c|c|c|c|}
\hline & 1990 & 1991 & 1992 & 1993 & 1994 & 1995 & 1996 & 1997 & 1998 & 1999 & Total \\
\hline Privatization (value) & 0 & 2096 & 2447 & 3026 & 620 & 1123 & 4829 & 16087 & 27540 & 3797 & 61564 \\
\hline $\begin{array}{l}\text { Privatization } \\
\text { (number of transactions) }\end{array}$ & 0 & 4 & 14 & 6 & 9 & 7 & 13 & 20 & 31 & 9 & 113 \\
\hline $\begin{array}{l}\text { Mergers and acquisitions } \\
\text { (value) }^{\mathrm{a}}\end{array}$ & 639 & 274 & 359 & 3329 & 1146 & 4734 & 6059 & 9899 & 26292 & 15161 & 67893 \\
\hline $\begin{array}{l}\text { Mergers and acquisitions } \\
\text { (number of transactions) }\end{array}$ & 13 & 20 & 27 & 49 & 55 & 90 & 129 & 154 & 264 & 254 & 1055 \\
\hline
\end{tabular}

Source: GIC-IE databank of the Federal University of Rio de Janeiro, based on information from Thomson Financial Securities.

${ }^{a}$ According to declared value of transactions.

TABLE 3

Brazil: Net revenue of firms and expenditure on innovation activities, 2000

\begin{tabular}{|c|c|c|c|c|c|c|c|}
\hline \multirow{3}{*}{ Number of firms } & \multirow{3}{*}{$\begin{array}{l}\text { Net revenue } \\
\text { (R\$ million) }\end{array}$} & \multicolumn{6}{|c|}{ Expenditure on innovation activities } \\
\hline & & \multicolumn{2}{|c|}{ Total } & \multicolumn{2}{|c|}{ Machinery acquisition } & \multicolumn{2}{|c|}{ Internal R\&D } \\
\hline & & $\begin{array}{c}\text { Number } \\
\text { of firms } \\
\text { (R\$ million) }\end{array}$ & $\begin{array}{c}\text { Value } \\
\text { (R\$ million) }\end{array}$ & $\begin{array}{l}\text { Number } \\
\text { of firms }\end{array}$ & $\begin{array}{c}\text { Value } \\
\text { (R\$ million) }\end{array}$ & $\begin{array}{l}\text { Number } \\
\text { of firms }\end{array}$ & Value \\
\hline 72005 & 582406.1 & 19165 & 22343.8 & 15540 & 11667.3 & 7412 & 3741.6 \\
\hline
\end{tabular}

Source: Industrial Survey on Technological Innovation (IBGE, 2000). 
IV

Industrial commodities:

Low cost for exports, differentiation

for the local market

\section{Pattern of competition then and now: widening and deepening the search for lower costs}

Commodity-related industries are engaged in the production of intermediate inputs for industrial or final consumption through large-scale production processes, and cost reduction is the driving factor in competition. Due to increasing competitive pressures from developing countries, markets of developed countries are being defended in favour of local firms by means of explicit protectionist measures (see first two columns of table 4).

Commodities are intrinsically undifferentiated, and production efficiency and economies of scale are ensured by three complementary means: highly capital-intensive plants, preferential access to inputs (raw materials and energy sources) and transport logistics. In such a context, large, multi-plant companies, operating internationally are capable of expanding the frontiers of the important competitive driving factors. During the last decade, local leading international firms have become larger and more internationalized through mergers and acquisitions.

At the level of the firm, core competences are related to five sources of competitive advantages: management, acquisition of or access to process technology, inputs, transport, and distribution networks and preferential clients. The diffusion of information systems based on microelectronics technologies has provided the technical base for co-ordinating largescale operations and logistics.

The pattern of competition among firms has remained closely associated with what is known as homogeneous oligopoly. Competing firms try to gain knowledge of market perspectives and behaviour of rivals, on a global basis. Thus, for competitive success, it is of fundamental importance to correctly anticipate demand growth and/or effectively respond to changes in price and quantity demanded by local and international markets.

Aggressive firms are those implementing merger/acquisition-based investment strategies and expanding capacity ahead of the growth in demand for current products. Revenue possibilities have expanded significantly in the past ten years, by means of widening product portfolio, exploring transportation assets for third parties or selling-off surplus energy. Preferential access to capital markets is of vital importance. In this respect, large and internationalized companies have considerable advantages over firms operating single plants or in a limited number of national markets.

International competition in a context of liberalized national economies has strengthened a historical trend: although prices of most commodities fluctuate in line with world economic cycles, relative prices have shown a declining trend, raising serious terms of trade problems for commodity-dependent exporting nations.

Steel, pulp and paper and concentrated orange juice, along with other commodity industries like soybeans and iron ore, are considered to be pillars of Brazilian international competitiveness. In these industries, in 2002, Brazil had a significant share of international export markets: $80 \%$ in concentrated orange juice, $37 \%$ in sugar, $34 \%$ in soybeans, $32 \%$ in coffee and $16 \%$ in the meat industry. In 1990, the relatively small size of leading companies and the low levels of product value-added were the main competitive challenges facing Brazilian commodity producers. Since then these challenges have been only partially addressed, while other sources of competitiveness have been enhanced (see last two columns of table 4). 
TABLE 4

Brazil: Patterns of competition and competitiveness in commodities: then and now

\begin{tabular}{|c|c|c|c|c|}
\hline $\begin{array}{l}\text { Sources of competitive } \\
\text { advantages }\end{array}$ & $\begin{array}{l}\text { Cost-based POC } \\
\text { Main factors of } \\
\text { competitiveness, } 1990\end{array}$ & $\begin{array}{l}\text { Cost-based POC } \\
\text { Main factors of } \\
\text { competitiveness, } 2002\end{array}$ & $\begin{array}{l}\text { Brazilian } \\
\text { competitiveness, } \\
1990\end{array}$ & $\begin{array}{l}\text { Brazilian } \\
\text { competitiveness, } \\
2002\end{array}$ \\
\hline \multicolumn{5}{|l|}{ Internal factors } \\
\hline Management & Process control & & Efficient & More efficient \\
\hline Production & $\begin{array}{l}\text { Mass flow and energy } \\
\text { efficiency }\end{array}$ & No change & Efficient & $\begin{array}{l}\text { More efforts in } \\
\text { energy control }\end{array}$ \\
\hline Sales & $\begin{array}{l}\text { Access to distribution } \\
\text { channels }\end{array}$ & & Efficient & More efficient \\
\hline Innovation & Process technology & & Incipient local efforts & Incipient local efforts \\
\hline \multicolumn{5}{|l|}{ Structural factors } \\
\hline Market & $\begin{array}{l}\text { Standardization } \\
\text { Price, technical conformity } \\
\begin{array}{l}\text { Access to international } \\
\text { trade }\end{array}\end{array}$ & No change & $\begin{array}{l}\text { Prominence in low } \\
\text { value added segments }\end{array}$ & $\begin{array}{l}\text { Low unit value for exports } \\
\text { and higher unit value for } \\
\text { local markets } \\
\text { Cyclical with changing } \\
\text { terms of trade }\end{array}$ \\
\hline $\begin{array}{l}\text { Configuration } \\
\text { of industry }\end{array}$ & $\begin{array}{l}\text { Company and plant } \\
\text { level economies of scale } \\
\text { Access to raw materials } \\
\text { and transport logistics } \\
\text { Specialized technical } \\
\text { services }\end{array}$ & $\begin{array}{l}\text { No change } \\
\text { Reasonable efforts }\end{array}$ & $\begin{array}{l}\text { Efficient plant size but } \\
\text { low size of companies; } \\
\text { prominence of } \\
\text { State-owned enterprises; } \\
\text { low investments abroad } \\
\text { Good access to inputs } \\
\text { and deficiencies in } \\
\text { logistics } \\
\text { Reasonable efforts }\end{array}$ & $\begin{array}{l}\text { Increased size but still } \\
\text { below international } \\
\text { benchmarks } \\
\text { More efficient }\end{array}$ \\
\hline $\begin{array}{l}\text { Regulation and } \\
\text { incentives regime }\end{array}$ & $\begin{array}{l}\text { Anti-dumping and trade } \\
\text { policy } \\
\text { Environmental protection } \\
\text { Cost of capital }\end{array}$ & $\begin{array}{l}\text { Increased importance } \\
\text { Increased importance } \\
\text { No change }\end{array}$ & $\begin{array}{l}\text { Trade restrictions } \\
\text { Some restrictions } \\
\text { High } \\
\text { Tax distortions } \\
\text { Risk of cartelization, } \\
\text { incipient privatization }\end{array}$ & $\begin{array}{l}\text { Stronger restrictions } \\
\text { Stronger restrictions } \\
\text { Still high } \\
\text { No change } \\
\text { Privatization completed } \\
\text { but ownership not } \\
\text { consolidated }\end{array}$ \\
\hline
\end{tabular}

Source: Prepared by the authors.

\section{Competitiveness in 2002: Ownership consoli- dation and product upgrading must continue}

\section{a) Increasing size of firms}

Privatization of the steel industry and mergers and acquisitions in pulp and paper have changed the ownership landscape of the commodities industrial group. Even so, when compared to their international counterparts, Brazilian firms remain relatively small and oriented towards the local market. Further changes may occur, leading to greater concentration of market structures and, perhaps, acquisitions by Brazilian firms of other corporations abroad.

In the steel industry, two outstanding processes have taken place: the privatization process initiated in the late 1980s, and a substantial investment drive in stages of the production process associated with the generation of new, higher unit value products to be sold on the local market.

Six large steel companies and six small ones were privatized in Brazil, for a total of US\$ 5.7 billion.

INDUSTRIAL COMPETITIVENESS IN BRAZIL TEN YEARS AFTER ECONOMIC LIBERALIZATION • JOÃO CARLOS FERRAZ, DAVID KUPFER 
Local capital predominated in the privatization process. Financial institutions accounted for $33.6 \%$, pension funds for $15 \%$ and industrial corporations for $21.8 \%$ of the total value of privatization. Due largely to the privatization technique used (i.e., auctions), an outstanding feature of the second half of the 1990s was ownership instability and further asset transactions. After privatization was completed 20 private merger and acquisition transactions were carried out. Between 1990 and 2000, only 17\% of the production units (measured in terms of physical capacity) had not undergone at least one change in ownership. Besides ownership changes, between 1994 and 2000 the industry invested an average of US\$ 1.4 billion. This was rather unexpected, given the country's macroeconomic uncertainties and those arising from the privatization process itself. Most investments were focused in the rolling area, enabling product upgrading.

In pulp and paper, at the end of the twentieth century, there were 220 companies. In 2000, total sales reached US $\$ 7.5$ billion; the largest 11 integrated companies were responsible for two-thirds of this total, showing the importance of plant- and company-level economies of scale for this industry. During that year, the four largest producers of pulp accounted for $70 \%$ of total production. In the paper segment, concentration levels are lower, but they have been increasing since 1990. In that year, the five largest producers were responsible for $39.5 \%$ of total production; ten years later that share had increased to $51.4 \%$. Ownership concentration levels were increased through a very active process of mergers and acquisitions, as shown in table 5.

TABLE 5

Brazil: Main mergers and acquisitions in the pulp and paper sector, 1992-2001

\begin{tabular}{lllll}
\hline Company sold & Controlling company & Date & Share & Product \\
\hline Simão & Votorantim & 1992 & $100 \%$ & Printing paper \\
Mad. Saguário & Orsa & 1996 & $100 \%$ & Wrapping paper \\
Nicolaus Papeis & Md Papeis & 1997 & $100 \%$ & Special paper + cardboard \\
Klabin Tissue & Kimberly Klabin & 1998 & $50 \%$ & Tissue \\
Inpacel & Champion / International Paper & 1998 & $100 \%$ & Lightweight coated paper \\
Celpav & Votorantim & 1988 & $100 \%$ & Printing paper \\
Igaras & Klabin/Riverwwod & 2000 & $100 \%$ & Pulp / kraftliner \\
Klabin & Joint Venture until 2002 & 2000 & $50+50 \%$ & Newsprint \\
& Norske Skog & & & \\
Jarcel & Orsa & 2000 & $100 \%$ & Pulp \\
& & & \\
Pisa & Norske Skog & 2000 & $100 \%$ & PAR + newsprint \\
Champion L. & International Paper & 2000 & $100 \%$ & Pulp + printing paper. \\
Bahia Sul & Suzano & 2001 & $100 \%$ & Pulp + paper \\
Cenibra & JBP & 2001 & $100 \%$ & Pulp \\
Portucel & Suzano + Sonae & 2001 & $28 \%$ & Pulp + paper \\
Aracruz & Votorantim & 2001 & $26 \%$ & Pulp \\
\hline
\end{tabular}

Source: Fonseca (2002).

TABLE 6

Brazil: Verticalization and supply contracts in the pasteurized orange juice production chain

\begin{tabular}{llllllr}
\hline $\begin{array}{l}\text { Selling } \\
\text { company (1) }\end{array}$ & $\begin{array}{l}\text { Distribution } \\
\text { company (2) }\end{array}$ & $\begin{array}{l}\text { Relation } \\
\text { between (1) and (2) }\end{array}$ & $\begin{array}{l}\text { Packaging } \\
\text { company (3) }\end{array}$ & $\begin{array}{l}\text { Relation between } \\
(2) \text { and (3) }\end{array}$ & $\begin{array}{l}\text { Processing } \\
\text { company (4) }\end{array}$ & $\begin{array}{r}\text { Relation between } \\
(3) \text { and (4) }\end{array}$ \\
\hline Nestle & Nestle & Vertical & Cargill & Contract & Cargill & Vertical \\
Dan' Fresh & Danone & Vertical & Citrovita & Contract & Citrovita & Vertical \\
Leco & Leco & Vertical & Citrovita & Contract & Citrovita & Vertical \\
Yes & Paulista & Contract & Cargill & Contract & Cargill & Vertical \\
Parmalat & Parmalat & Vertical & Parmalat & Vertical & Parmalat & Vertical \\
Carrefour & Carrefour & Vertical & Cargill & Contract & Cargill & Vertical \\
Sendas & Sendas & Vertical & Nova América & Contract & Nova América & Vertical \\
\hline
\end{tabular}

Source: Compiled from Neves and Marino (2002). 
In the citrus industry there are two segments. In the frozen concentrated orange juice segment, firms control the processing stage and co-ordinate the associated logistics (from orange plantations to packaging). Most active firms have moved to the south of the USA, acquiring or investing in new processing units and even some plantations. Co-ordination capabilities have been developed and important clients, like Coca-Cola, have transferred the management of their production units in the United States to a Brazilian company. This is an important change from the early 1990s, due to the need to sidestep import restrictions. The industry has also become more concentrated: the export share of the four largest producers increased from $70 \%$ to $90 \%$ between 1997 and 2001. But these firms still remain distant from final consumers: they are typical commodity producers, relying for competitiveness on the low cost of their undifferentiated product.

In the pasteurized orange juice segment, which has been expanding rapidly in Brazil, the market structure is different. As shown in table 6, in their search for economies of scale firms have followed different verticalization strategies. At one extreme, close to the resource base, processing firms have verticalized into packaging operations. At the other extreme, close to the final consumer, companies have incorporated distribution activities. In most cases, economic relations between these two extremes involve supply contracts between different companies.

\section{b) Low unit value for exports, high unit value for the local market}

Brazilian commodity producers supply international markets predominantly with low unit value products. Since the early 1990 s they have consolidated their competitive position by investing in distribution networks and closer relations with large clients. For the Brazilian market, however, firms have evolved towards widening and upgrading their product portfolio. Compared with exports, sales to the local market have higher unit value. This dual track strategy has been consolidated throughout the years. It remains to be seen whether the experience gained in the local market may prove useful for conquering new and more valuable segments in international markets in the years to come.

In 1999, in value terms, the world share of Brazilian steel semi-finished products was $14.1 \%$, but in galvanized sheets it was only $0.4 \%$, while the share of semi-finished products in total Brazilian steel exports increased from $39.2 \%$ in 1990 to $68.4 \%$ in 2001 , in terms of physical production. This expansion was attained in spite of the context of increasing protectionist barriers. In the local market, however, total steel consumption increased $89 \%$ between 1992 and 2001, while the growth in galvanized sheets reached $402 \%$. Over $50 \%$ of total demand came from the automotive and civil construction sectors.

\begin{tabular}{|c|c|c|c|c|c|c|c|}
\hline & \multicolumn{7}{|c|}{$\begin{array}{l}\text { Brazil and other selected countries: Production costs of cold rolled sheet steel, } \\
\text { April } 2001 \\
\text { (US\$/dispatched ton) }\end{array}$} \\
\hline & United States & Japan & Germany & United Kingdom & S. Korea & China & Brazil \\
\hline Raw materials & 115 & 106 & 109 & 105 & 112 & 118 & 103 \\
\hline Coal & 27 & 27 & 26 & 24 & 28 & 28 & 37 \\
\hline Iron ore & 55 & 56 & 62 & 58 & 59 & 75 & 40 \\
\hline Scrap / Direct reduction iron & 33 & 26 & 21 & 23 & 25 & 15 & 26 \\
\hline Other raw materials & 172 & 150 & 148 & 153 & 134 & 152 & 135 \\
\hline Labour costs ${ }^{\mathrm{a}}$ & 154 & 142 & 136 & 113 & 62 & 26 & 57 \\
\hline Hourly wage & 38 & 36 & 34 & 27.6 & 13 & 1.25 & 10.5 \\
\hline Total operational costs & 441 & 398 & 392 & 371 & 308 & 297 & 295 \\
\hline Financial costs & 39 & 60 & 40 & 46 & 42 & 50 & 67 \\
\hline Depreciation & 29 & 40 & 30 & 26 & 30 & 30 & 32 \\
\hline Interest & 10 & 20 & 10 & 20 & 12 & 20 & 35 \\
\hline Total cost & 480 & 458 & 432 & 417 & 350 & 347 & 362 \\
\hline
\end{tabular}

Source: Paula (2002)

a In man-hours per ton. 
The high level of competitiveness in low value added products is also reflected in the industry's cost structure. As may be seen from table 7, the competitiveness of the Brazilian steel industry stems from the low level of labour and iron ore costs. Financial costs and the cost of coal have long been the basic source of competitive disadvantage.

Cost advantages in pulp production are quite similar. In 2001, Brazilian industry led in the production of short fibre pulp, with a $19.4 \%$ share of total world supply, a 7-point increase over the 1990 market share. Between 1990 and 2001 this branch expanded by 9.5\% annually, surpassed only by the expansion of Indonesia, a latecomer to the industry. In value terms, exports increased from US\$ 556 million in the early 1990s to US\$ 1.3 billion in 2000.

In paper production the picture is very different, both in terms of volume of production and share in world markets. In 2000, Brazil produced 7,188 tons of paper, while international production reached 323,295 tons. Although the Brazilian industry grew by $4.3 \%$ during the 1990s, its international market share for all types of papers is very small and has remained unchanged: $2.0 \%$ in 1991 and $2.2 \%$ in 2000 .

Five types of papers accounted for more than $50 \%$ of exports in 2000 - printing/writing, non-coated paper, toilet paper, cardboard and kraft liner. Ten years before, the proportion was higher, at 70\%. Since 1990, however, in value terms paper exports have remained below US\$ 1 billion in most years. Thus, in 2000, $62 \%$ of total paper production was sold in the local market; $22 \%$ represented self-consumption by the producers and only $15 \%$ was exported.

The citrus industry follows a similar dual track strategy. In the frozen concentrated orange juice (FCOJ) segment, Brazil is an international leader; in the pasteurized orange juice (POJ) segment sales are directed to the local market. The latter requires more sophisticated industrial operations and is very close to the final consumer market, requiring significant marketing efforts.

During the 1990s $50 \%$ of total world orange juice and $80 \%$ of FCOJ were produced in Brazil, generating, on average, US\$ 1 billion in foreign exchange. Like other commodity producers, Brazil is very dependent on the fluctuations of international prices. While total exports of FCOJ expanded from 785 million tons in 1990 to 1,234 million in 2000, export revenues reached a peak of US\$ 1.3 billion in 1995 , decreasing to US\$ 800 million in 2001.
Most developed markets for FCOJ are stagnating, while developing regions are expanding their consumption. It is estimated that West Europeans consume 24 litres of fruit juice per year, while East Europeans consume 5 litres per year, having increased their consumption $80 \%$ between 1995 and 2000. This context has led to reactions from important consumer/producer countries through the imposition of trade barriers, like the $56 \%$ ad valorem tariff imposed by the United States. In the POJ segment market perspectives are positive. While annual consumption levels of POJ in the USA reach 40 litres, in Brazil total orange juice consumption is around 20 litres/year. Of that, only 1 litre is POJ, but annual rates of growth in this segment are very high, at around 30\%.

\section{c) Cost control}

Throughout the 1990s, companies placed considerable emphasis on actions closely associated with the reduction of direct costs, especially raw materials and transport. Lowering energy costs was an important investment item, given its high weight in total costs and the supply crisis the country faced in 2001. Companies also consolidated their capabilities to operate technically updated plants efficiently, but they still relied on capital goods suppliers to define the technological possibilities of improving processes.

The investment drive in the steel industry had a direct impact on efficiency levels. Even though output levels remained around 25 million tons per year, modernization of installations and sharp cuts in employment levels - at an annual average rate of $7.6 \%$ between 1989 and 2000 resulted in corresponding marked improvements in productivity levels, from 11 to 5.4 man-hours per ton, between 1991 and 2000 (see figure 3).

Investments in pulp and paper were not as pronounced as in steel, but in order to maintain their competitiveness firms expanded backward integration towards rationalized eucalyptus forests. In 1990, out of 64 million hectares planted by the industry, eucalyptus forests occupied 42 million and pine forests 20 million. Ten years later, the area of pine plantations remained constant while 100 million hectares of eucalyptus forests were planted.

The competitiveness of the citrus sector also lies in its privileged access to inputs. There have been considerable technological efforts to improve the productivity of the agricultural base of the industry. The most significant achievement was the 2002 DNA 
sequencing of the genome of the bacteria Xyllela Fastidiosa, which causes diseases in the crops. According to Neves and Marino (2002), productivity has expanded due to increasingly intensive plantation management and greater use of fertilizers, while the total area planted has decreased.

FIGURE 3

Brazil: Output and employment in the steel industry, 1988-2001

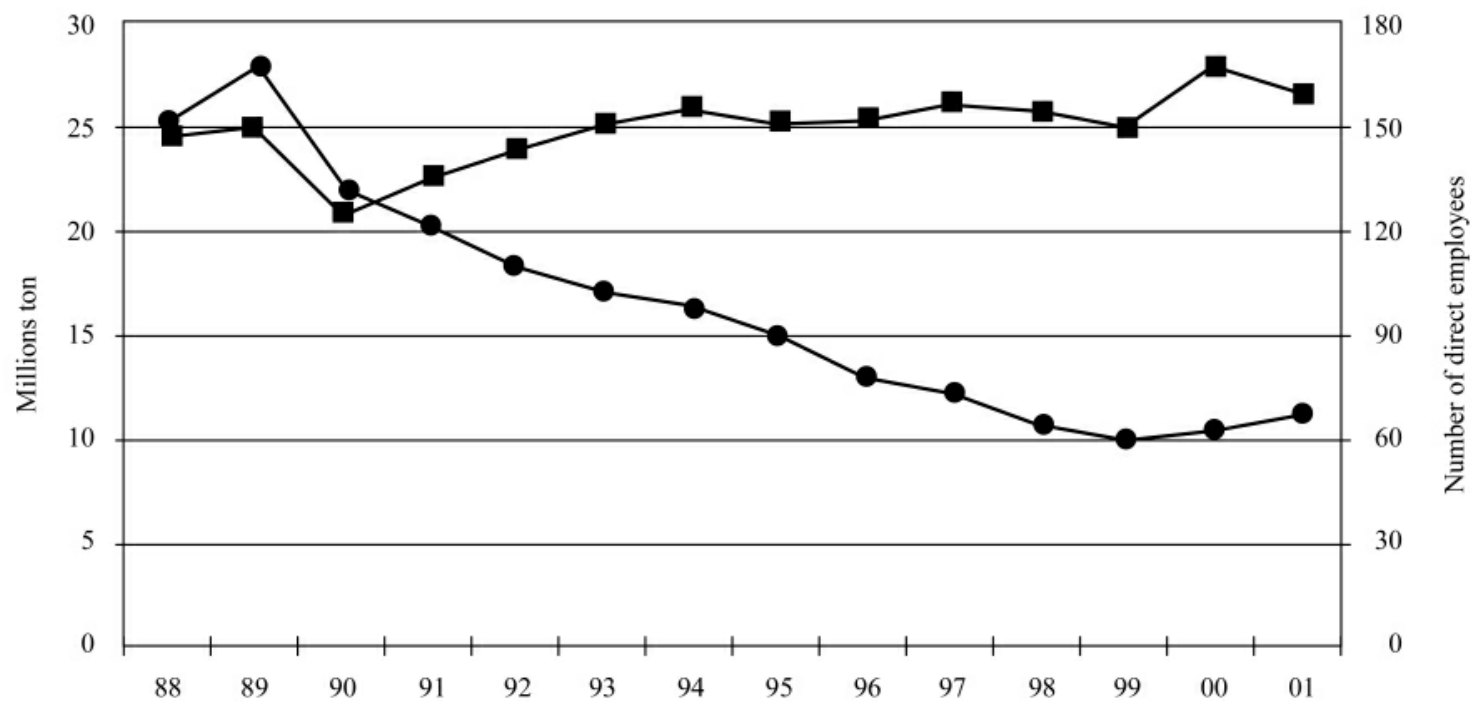

Production $\longrightarrow$ Number of employees

Source: Paula, 2002

V

\section{Durable goods: Inward internationalization and catching up in middle income segments}

\section{The pattern of competition then and now:} internationalization and differentiation

The market structure of durable industries, like the consumer electronics and automobile industries, is characterized by differentiated and concentrated oligopolies, with just a few firms operating in global markets. Leading firms are those capable of successfully exploiting economies of scale and scope. The 1990 international competitive drivers have been further stressed (see first two columns of table 8). For competitive firms, differentiation requires constant introduction of products with new sets of attributes. For this purpose, firms invest in product development, marketing, and after-sales service through an authorized retailers' network. Firms are constantly trying to create or expand market segments, in order to pay off the investments costs associated with product development and new or renewed installations.

To be competitive it is mandatory to operate under strict minimum requirements of technical and management economies of scale. Scale is therefore a significant barrier to entry, and firms must implement 
investment strategies that anticipate market growth. It is also important to operate production systems with increasing levels of technical efficiency, quality and flexibility. These needs imply the intensive use of microelectronics-based automation and organizational techniques oriented towards continuous improvement of production processes.

Due to the heavy weight of components in total production cost, vertical disintegration has increased, combined with new forms of linkages between assemblers and suppliers. In relation to suppliers, essential competitive factors are: delivery times; price; technical conformity; stable industrial contracts incorporating the transfer of inventory administration costs to suppliers; and joint development of components. The prevailing international context of trade liberalization has induced firms to develop global sourcing systems. For some lines of electronics-based consumer goods, there has also been an important trend towards subcontracting the production of final goods to specialized contract manufacturing firms in developing countries like Mexico and China.

Investments made in these sectors normally induce dynamic effects in a host economy, directly or indirectly, including changing and upgrading the nature of employment of a region. This is why local authorities offer generous fiscal incentives to attract these sets of activities.

TABLE 8

Brazil: Patterns of competition (POC) and competitiveness in durables, then and now

\begin{tabular}{|c|c|c|c|c|}
\hline $\begin{array}{l}\text { Sources of } \\
\text { competitive } \\
\text { advantages }\end{array}$ & $\begin{array}{l}\text { POC based on differentiation } \\
\text { Main driving factors } \\
\text { in } 1990\end{array}$ & $\begin{array}{l}\text { POC based on differentiation } \\
\text { Main driving factors } \\
\text { in } 2002\end{array}$ & $\begin{array}{l}\text { Brazilian } \\
\text { competitiveness } \\
\text { in } 1990\end{array}$ & $\begin{array}{l}\text { Brazilian } \\
\text { competitiveness } \\
\text { in } 2002\end{array}$ \\
\hline \multicolumn{5}{|l|}{ Internal factors } \\
\hline Management & Co-ordination capabilities & & Lack of capabilities & Closing gap \\
\hline Production & Organizational flexibility & & Organizational rigidity & Closing gap \\
\hline Sales & Brand image & $\begin{array}{l}\text { No change, with increasing } \\
\text { importance of information } \\
\text { technologies }\end{array}$ & Brand image & Closing gap \\
\hline Innovation & $\begin{array}{l}\text { Product and component } \\
\text { design }\end{array}$ & & $\begin{array}{l}\text { Local design capabilities } \\
\text { but outdated products } \\
\text { sourcing of updated }\end{array}$ & $\begin{array}{l}\text { Demobilization of local } \\
\text { capabilities and out } \\
\text { products }\end{array}$ \\
\hline \multicolumn{5}{|l|}{ Structural factors } \\
\hline \multirow[b]{2}{*}{ Market } & $\begin{array}{l}\text { Segmentation by quality } \\
\text { and marketing }\end{array}$ & Increased & Low segmentation & $\begin{array}{l}\text { Specialization in middle } \\
\text { range segments }\end{array}$ \\
\hline & $\begin{array}{l}\text { Price, brand, technological } \\
\text { content, technical assistance } \\
\text { Regional and global trade }\end{array}$ & $\begin{array}{l}\text { Increased } \\
\text { Increased }\end{array}$ & $\begin{array}{l}\text { High price, low } \\
\text { technological content } \\
\text { Distant from } \\
\text { international networks }\end{array}$ & $\begin{array}{l}\text { Closing gap } \\
\text { Increased exports; } \\
\text { resistance to imports }\end{array}$ \\
\hline \multirow{3}{*}{$\begin{array}{l}\text { Configuration } \\
\text { of industry }\end{array}$} & $\begin{array}{l}\text { Firm and plant level } \\
\text { economies of scale and scope }\end{array}$ & Increased & $\begin{array}{l}\text { Scale deficiencies in } \\
\text { most product lines }\end{array}$ & $\begin{array}{l}\text { Optimization through } \\
\text { specialization }\end{array}$ \\
\hline & $\begin{array}{l}\text { Assembler-supplier linkage, } \\
\text { distribution }\end{array}$ & Increased & Incipient linkages & $\begin{array}{l}\text { Closer relations with } \\
\text { suppliers;increasing } \\
\text { reliance on global } \\
\text { supply chains }\end{array}$ \\
\hline & $\begin{array}{l}\text { Metrology and } \\
\text { standardization }\end{array}$ & No change & Adequate & Adequate \\
\hline \multirow{4}{*}{$\begin{array}{l}\text { Regulation and } \\
\text { incentives regime }\end{array}$} & Property rights & No change & $\begin{array}{l}\text { Low levels of } \\
\text { compliance }\end{array}$ & $\begin{array}{l}\text { Enforcement of property } \\
\text { rights }\end{array}$ \\
\hline & Consumer protection & No change & Incipient legislation & Stricter legislation \\
\hline & Consumer credit & No change & Non-existent & $\begin{array}{l}\text { Variation according to } \\
\text { macroeconomic conditions }\end{array}$ \\
\hline & Fiscal incentives & No change & Non-existent & $\begin{array}{l}\text { Extensive use of local } \\
\text { incentives }\end{array}$ \\
\hline
\end{tabular}

Source: Prepared by the authors. 
In Brazil, the consumer electronics and automotive industries were strongly impacted by the Plano Real and trade liberalization. On the one hand, an "income effect" sharply expanded demand levels; on the other hand, trade liberalization imposed new and more rigid benchmarks for product attributes, such as price and technical specifications.

During the 1990s, firms in Brazil not only demonstrated the capacity to resist international competition but also to implement pro-active strategies to exploit the expansion in demand through investment in new production capacity and higher levels of imports of parts and components (see the last two columns of table 8). New entries took the form of green field investment, especially in automobile assembly, and acquisition of existing auto parts businesses. New entrants in consumer electronics combined both investment modes. By 2002, the internationalization of ownership, already a structural feature in these industries, was practically complete. Representatives of most international leading players are currently operating in Brazil. As a result, Brazil has become an important production platform for middle-range products, such as sub-compact cars, on the international scene. Given the oscillating, low-growth trends of the Brazilian economy throughout the decade, however, most firms have yet to make full use of the new installations.

\section{Competitiveness in 2002: successful catching up, but demand constraints still impose limits on further growth}

\section{a) Capacity expansion and internationalization}

In consumer electronics, the market expansion of the first half of the 1990s induced the entry of new players and the growth of existing competitors. New investments (and entrants) were observed in the television and video segment, while mergers and acquisitions were more pronounced in the freezers, refrigerators, cookers and washing machines segments.

The industry went through two different phases. After the period of recession in the early 1990s, manufacturers of audio and video products improved performance due to significant increases in consumption levels, mostly among lower social classes. For instance, sales of TV sets, which were about 2 million units in 1990, increased to the unprecedented level of 8.5 million units by 1996. But, just as production expanded in that period, it quickly contracted during the second half of the 1990s, falling to nearly half the 1996 volume by the end of the decade (Sá, 2002).

The high levels of credit default among lowbudget consumers damaged the sales of major shopping outlets, leading to the bankruptcy of some leading chains and thus reducing the sales revenue of most

TABLE 9

Brazil: New assembly plants in the automotive sector, 1996-2001

\begin{tabular}{lll}
\hline Firm & Type of product & Location \\
\hline Volkswagen & Engines & São Carlos-SP \\
Volkswagen & Lorries and buses & Resende-RJ \\
Honda & Cars & Sumaré-SP \\
Mitsubishi & Light commercial vehicles & Catalão-GO \\
Renault & Cars and engines & São José dos Pinhais-PR \\
Toyota & Cars & Indaiatuba-SP \\
Daimler Chrysler & Cars & Campo Largo- PR \\
GM & Components & Mogi das Cruzes-SP \\
Volkswagen-Audi & Cars & São José dos Pinhais-PR \\
Mercedes & Cars & Juiz de Fora - MG \\
GM & Cars & Gravataí-RS \\
Iveco & Engines & Sete Lagoas-MG \\
Ford & Cars & Camaçari-BA \\
Nissan & Light commercial vehicles & São José dos Pinhais-PR \\
Peugeot-Citroen & Cars and engines & Porto Real-RJ
\end{tabular}

Source: Sarti (2002) 
electronics manufacturers. As a result, the consumer electronics industry went through a reorganization process which included the bankruptcy of some local firms and the closing down of local operations by foreign firms.

The inverted V shape of television sales shows how volatile the Brazilian economy has been and, from a technical perspective, how production of consumer electronics items can be expanded and reduced very quickly, enabling firms to respond to positive and negative evolution in demand.

In car assembly, green field investment prevailed. Table 9 shows the impressive addition of new capacity to the segment during the second half of the 1990s both by existing producers and newcomers.

While new entrants and plants in car assembly increased competitive pressures, investments in auto parts also brought in new firms, but not via green field projects. Following international trends, mergers and acquisitions was the dominant mode of entry. Hence, as only a small proportion of resources were devoted to production expansion, higher rates of internationalization and market concentration were observed. In 1994, local capital accounted for at least $50 \%$ of total capital, sales and investment, but by the end of the decade, the share of locally owned firms was down to approximately $25 \%$.

The performance of this industrial group was very much influenced by the evolution of aggregate demand. For example, in 2000 the sales revenue of the audio and video markets plummeted to US\$ 3.5 billion: far below the US\$ 8.1 billion reached in 1996 . Idle capacity is more pronounced in auto producers, as they are not able to shut down capacity as easily as producers in the consumer electronics sector.

\section{b) Specialization and modernization}

By 2002, the Brazilian consumer electronics and automotive industries became specialized in middlerange segments. Firms invested in upgrading technical specifications to international levels, while relying on established technology standards, imported components and imported finished products for the lower and upper-end segments. This option can be explained by two factors: firstly, the size and income profile of local demand, and secondly, the competitive pressure from imports, which imposed strict minimum levels of product attributes.

This industrial branch has yet to compensate the volatile local demand with greater exposure to international trade; exports in the audio and video segments have remained at around US\$ 350 million since 1990 , representing a very small proportion of local sales; imports of final goods were around US\$ 150 million, increasing to US\$ 450 million when local demand expanded. The main destinations of exports were Argentina, Hungary, Italy and Spain. The infant but growing exports have not been able to compensate for the significant increase in the value of imports of electronic components from South Korea and Japan, however. According to Sá (2002), although total trade deficit in electronic components decreased from US\$ 1.5 billion in 1997 to US\$ 1.1 billion in 2000, the lack of production capacity in this segment constitutes a major structural weakness of Brazil.

In the automotive sector, regardless of ownership changes, investments were significant and the Brazilian competitive gap was significantly reduced in terms of product attributes and efficiency levels of installations. In aggregate terms, as shown in table 10 , the number of cars produced per worker per year has trebled between 1990 and 2001, reaching 21.3 units. At the same time employment fell from 117,396 posts in 1990 to 85,257 in 2001 , in spite of new investments.

TABLE 10

Brazil: Employment and productivity in the car assembly sector, 1990-2001

\begin{tabular}{lrrrrrr}
\hline & 1990 & 1992 & 1994 & 1996 & 1998 & 2001 \\
\hline Employment & 117396 & 105664 & 107134 & 101857 & 83049 & 85 \\
\begin{tabular}{l}
$\begin{array}{l}\text { Labour } \\
\text { productivity }\end{array}$ \\
\hline
\end{tabular} & 7.8 & 10.2 & 14.8 & 17.7 & 19.1 & 21.3 \\
\hline
\end{tabular}

Source: Sarti (2002)

a Units per worker in the year in question. 
At this point, it is important to call attention to changes in the nature of assembly-supplier relations in the automotive sector. Firstly, suppliers were induced to set up production facilities very close to assembly units, to enable de-verticalization and just-in-time operations. Most new plants were designed under the condominium concept, in which specific areas were designated to be occupied by selected auto parts corporations that would enjoy exclusive relations with assemblers. In return they had to share investment costs. Secondly, in line with new forms of relations, auto parts companies -now for the most part subsidiaries of key international players- developed intense intra-firm trade, thereby expanding auto parts imports from their parent transnational corporations. Between 1989 and 2001, auto parts imports increased $300 \%$, reaching US\$ 4.3 billions in 2001, with a trade deficit of US\$ 445 million.

Within a context of capacity expansion, modernization and ownership change, auto sales in Brazil increased from 713,000 units in 1990 to 1.9 million in 1997, going down to 1.6 million units in 2001. Most auto assemblers operating in Brazil focused on the subcompact segment, with engines in the 1000 to 2000 cc range. In $2001,71 \%$ of domestic production was related with this segment. The international trade of the Brazilian auto industry was marked by strong complementarities with Argentina: after a brief expansion in the post-trade liberalization years, the level of cars imports was reduced to US\$ 2 billion in the 2000/2001 biennium. Almost 66\% of these imports came from Argentina. By the same token, $44 \%$ of Argentine auto imports come from Brazil.

\section{VI}

\section{Traditional industries: competitive constraints are still defined by unequal income levels}

\section{The pattern of competition then and now: market segmentation and networking}

Market segmentation is an inherent feature of traditional industries. Variety prevails, in terms of number and technical specifications of products, nature of production processes (assembly, flow and batch production), minimum size of technical economies of scale, levels of verticalization and outsourcing, and organizational format of the companies.

Industrial sectors are very sensitive to oscillations in demand, and responsiveness is the key competitive driver of these industries (see first two columns of table 11). Responsiveness is important for two reasons. Firstly, through considerable marketing efforts, companies constantly try to introduce new designs and create niches to impose themselves in their markets. If successful, immediate demand expansion follows. When this happens, they must increase production levels to correspond with growth in demand, while keeping delivery times under control. Secondly, demand levels are subject to seasonal oscillations, imposing the need for constant adaptation of production levels. Compliance with these two sources of oscillations in demand is facilitated by the relative technical simplicity of production processes and the low investment costs in expanding capacity. Apart from the importance of imposing new consumer habits, investment in these industries is closely associated with changes in demand levels.

The degree of market segmentation is defined by the size and income profile of a given consumer population. The higher the income level, the less relative importance the price attribute will have and the greater the value of attributes associated with satisfying particular specifications of clients. Nationwide, if high income levels prevail, firms with similar competences will co-exist, while operating in different market segments. In contrast, when income differentials are significant, firms with very differentiated competences will co-exist in similar markets. It is important to note that, given the relatively low unit value of traditional products in consumer baskets, high levels of product renovation and differentiated competences among firms may prevail, even in a context of very unequal income levels, if the absolute size of the market is considerable, as in the case of Brazil.

Entrepreneurial skills for promoting product renovation and keeping organizational formats up to date 
-especially in regard to design, marketing, quality control systems and relations with suppliers- are essential for competitive success in traditional industries. The basic sources of technical change for these industries are the equipment and input supplier industries. In the past ten years an increasing role has been played by information technology-related equipment and chemical inputs. Those corporations capable of gaining access to such equipment and inputs on better terms will enjoy competitive advantages.

TABLE 1

Brazil: Patterns of competition and competitiveness in traditional industries: then and now

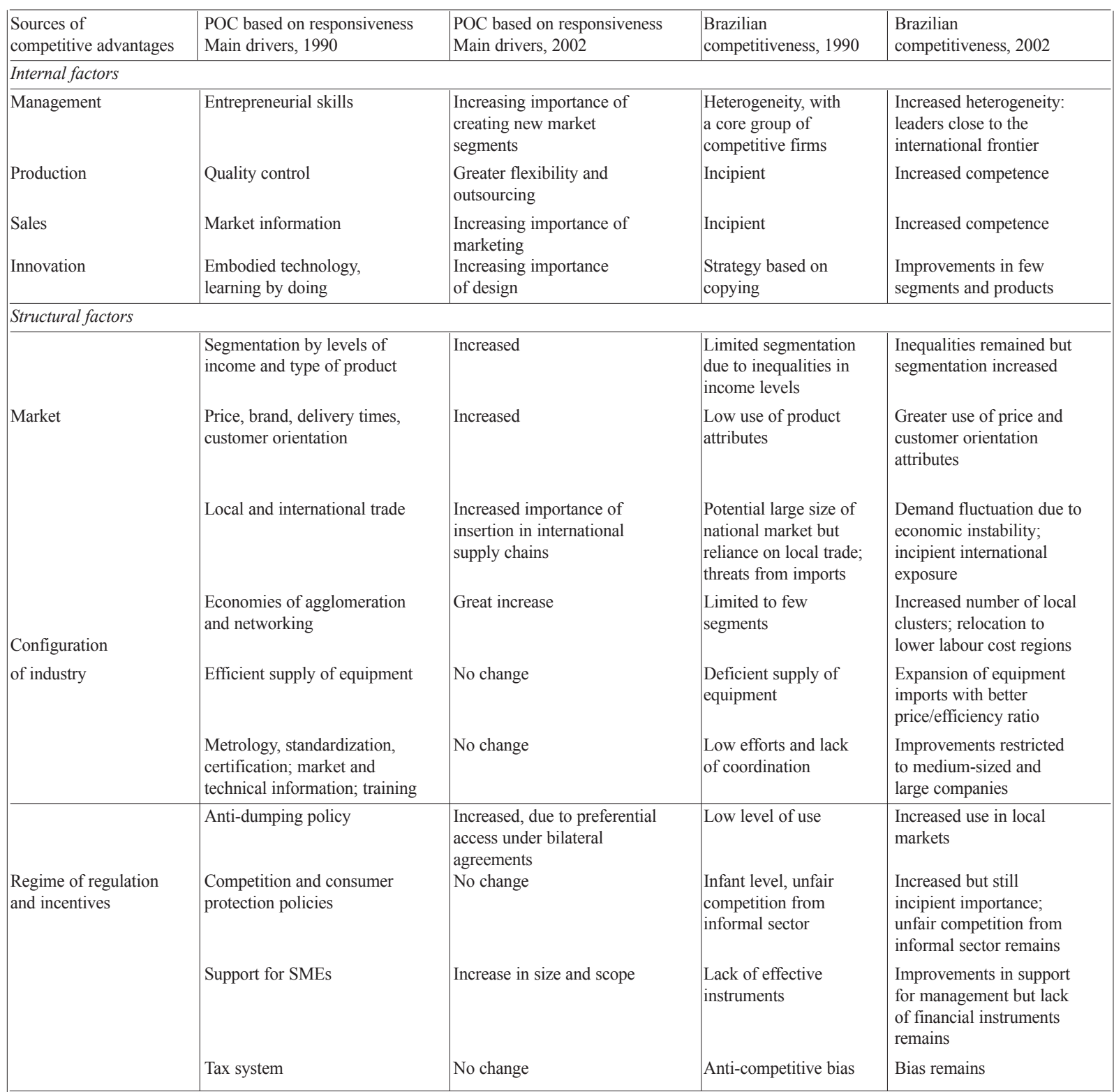

Source: Prepared by the authors. 
Privileged access to suppliers is related to size: smaller companies can survive in specific market niches, but they may face economic and financial difficulties in mobilizing the resources they need to fully exploit equipment- and input-related sources of competitive advantage. Given the inherent economic variety of these industries, this may be the basic reason for the growing trend for companies to organize themselves horizontally and/or vertically around local production clusters. Through such local clusters, companies can benefit from another source of competitive advantage: economies of agglomeration, through which they share costs associated with all aspects of their economic activity: infrastructure, labour and other inputs, design and marketing, information systems, etc.

Traditional industries are among the oldest industrial activities in Brazil, and competitive heterogeneity was and still is an important structural feature. The coexistence of very differentiated levels of competence among firms in each sector -and even among stages of production, within a given firm- can be directly associated with the country's remarkably uneven income distribution profile.

In 1990 competitiveness was directly associated with size: large firms were likely to be more competent than their smaller counterparts. Larger firms were able to explore different market segments, to invest in modernization and to export. The analysis of textile, footwear and furniture industries indicates that, in 2002, such structural feature still prevailed, although, as shown in the last two columns of table 11, some progress has been observed. The rate of product renovation has increased, through explicit and increased design efforts. Production modernization has been facilitated by the incorporation of more efficient machinery. Local clusters have emerged and are being consolidated in different industrial segments and regions of the country, while companies have further explored low labour cost opportunities, by transferring installations to the Northeast of the country.

\section{Competitiveness in 2002: increasing respon- siveness, but heterogeneity still prevails}

\section{a) Asymmetric capabilities}

The footwear industry exports $30 \%$ of its total production, while the textiles and garment industries focus on the domestic market. Until the mid-1990s, most footwear exports were directed to low-end market segments, where the price attribute is important. In spite of competitive pressure from Chinese producers, export performance has evolved positively during the 1990s. As shown in table 12, exports increased from US\$ 1.1 billion in 1990 to US\$ 1.6 billion in 2001 . Unit prices have also increased, indicating that the industry is upgrading its product portfolio. It is necessary to bear in mind that, since 1999 , devaluation has helped exports.

TABLE 12

Brazil: Footwear exports, selected years

\begin{tabular}{lccr}
\hline Year & Value (US\$ million) & Pairs (millions) & Average unit price (US\$) \\
\hline 1990 & 1107 & 143 & 7.74 \\
1995 & 1414 & 138 & 10.25 \\
2000 & 1547 & 163 & 9.52 \\
2001 & 1615 & 171 & 9.43 \\
\hline
\end{tabular}

Source: Costa (2002).

TABLE 13

Number of establishments, employment and sales revenue in the textile, chemical fibres and garment industries, 2000

\begin{tabular}{lccr}
\hline & Chemical fibres & Textiles & Garments \\
\hline Establishments & 25 & 3305 & 18797 \\
Employment (1,000 jobs) & 15 & 339 & 1233 \\
Production (1,000 ton/year) & 640 & 1750 & 1287 \\
Annual sales (US\$ billion) & 1.4 & 16.6 & 27.2 \\
\hline
\end{tabular}

Source: Prochnik (2002). 
Other factors have also contributed to the sector's international performance: fiscal incentives and export credits; the consolidation of gains from economies of agglomeration, especially in the southern state of Rio Grande do Sul, and the accumulated export experience. Nevertheless, labour costs still provide an important competitive edge to Brazilian production. In 1993 labour costs in Brazil were US\$ 1 per man-hour, compared to US\$ 0.5 in China, US\$ 2.5 in Korea and US\$ 8 in Spain. A study by Costa (2002) demonstrates the importance of the exchange rate to this export sector. During the 1994/1998 period, when the Real was overvalued, total employment fell by 56,000 , but as demand expanded -between 1999 and 2000 exports increased by US $\$ 270$ million (26 million pairs of shoes)- companies quickly contracted 29,000 more workers.

In the textiles sector there are important econom- ic differences between the three most important segments -textiles, chemical fibres and garments - as shown in table 13.

The combined sales of 22,000 establishments, employing 1.5 million workers, amounted to US\$ 45.2 billion in 2000. The production of chemical fibres is technically more complex and the plants are larger and generally controlled by foreign-owned firms. At the other extreme, in the garment industry, small and medium-sized locally-owned firms prevail, employing 1.2 million workers in 18,000 establishments.

In contrast with the footwear industry, the international performance of the Brazilian textile industry, as shown in table 14, was never economically significant, even though in some segments, such as the garment industry, the competitiveness drivers are similar to those prevailing in the footwear industry.

TABLE 14

Brazil: World trade and Brazil's share in the textiles and garment sectors, 1995-2000

\begin{tabular}{|c|c|c|c|c|c|c|}
\hline Textiles & 1995 & 1996 & 1997 & 1998 & 1999 & 2000 \\
\hline World trade (US\$ billion) & 111.1 & 113.6 & 119.3 & 112.5 & 113.0 & 126.1 \\
\hline Brazil's share in exports (\%) & 0.90 & 0.89 & 0.86 & 0.79 & 0.73 & 0.71 \\
\hline Brazil's share in imports (\%) & 1.23 & 0.98 & 1.01 & 0.95 & 0.79 & 0.88 \\
\hline \multicolumn{7}{|l|}{ Garments } \\
\hline World trade (US\$ billion) & 124.0 & 128.7 & 141.9 & 149.3 & 150.0 & 165.5 \\
\hline Brazil's share in exports (\%) & 0.24 & 0.19 & 0.15 & 0.12 & 0.12 & 0.17 \\
\hline Brazil's share in imports (\%) & 0.30 & 0.29 & 0.32 & 0.25 & 0.14 & 0.11 \\
\hline
\end{tabular}

Source: Compiled from Prochnik (2002).

\section{b) Modernization and relocation of production}

A modernization drive was also observed in this industrial group, but with very special features, including relocation towards the low-cost Northeast region of Brazil.

In the footwear industry, companies modernized production processes and product portfolio, including the introduction of automated equipment and new organizational techniques associated with raising quality and decreasing waste and down time. There were also concerted efforts to increase product lines in association with higher process flexibility.

In the textiles and garment sector, modernization was stimulated by three sources of dynamism. Firstly, during the first half of the 1990s, the Plano Real induced positive expectations in relation to growth of demand; secondly, starting in 1995, the National
Economic and Social Development Bank, BNDES, financed a US\$ 2 billion programme for machinery acquisition, especially for larger firms; and thirdly, import liberalization and an overvalued Real on one hand, and advances in technology, on the other, offered the possibility of importing updated machinery at lower prices. Investments in new machinery implied changes in production processes, with a negative impact on employment levels in the sector, which, as in other countries, fell substantially (by 40.7\%) between 1990 and 2000.

Concurrently, a significant number of companies in these sectors migrated from the Southeast to the Northeast (table 15), looking for lower labour costs and generous tax incentives, including VAT exemptions, the provision of physical infrastructure and export credit lines. 
TABLE 15

Brazil: Share of different regions in textile production, 1990-2000

\begin{tabular}{|c|c|c|c|c|c|c|c|}
\hline \multirow[t]{2}{*}{ Sector } & \multicolumn{2}{|c|}{ Northeast } & \multicolumn{2}{|c|}{ Southeast } & \multicolumn{2}{|c|}{ South } & \multirow[t]{2}{*}{ Total } \\
\hline & 1990 & 2000 & 1990 & 2000 & 1990 & 2000 & \\
\hline Fibres & 24.9 & 35.4 & 55.2 & 42.6 & 17.2 & 21.7 & 100 \\
\hline Fabrics & 17.6 & 21.5 & 65.6 & 62.0 & 12.8 & 13.7 & 100 \\
\hline Knitwear & 2.8 & 10.0 & 39.9 & 35.2 & 55.7 & 53.5 & 100 \\
\hline Garments & 8.0 & 11.3 & 66.6 & 56.1 & 21.6 & 25.4 & 100 \\
\hline Total & 13.3 & 19.6 & 56.8 & 49.0 & 26.8 & 28.5 & 100 \\
\hline
\end{tabular}

Source: Prochnik 2002

\section{VII \\ Innovation carriers: progress, setbacks and a fragile competitiveness}

\section{The pattern of competition then and now: the increasing role of innovation}

Innovation carriers are firms that engage in activities capable of inducing progress in other economic activities, through technical change incorporated in capital goods and components they produce. Market segmentation is the main feature of the demand for such goods. Since their products have specific applications, in general each firm competes directly with very few rivals. Over the years, and with the pervasive spread of information technologies, the leaders in this sector have evolved from supplying equipment and have become providers of technical solutions and services to clients.

Firms of this type must devote considerable resources to research and development $(\mathrm{R} \& \mathrm{D})$ activities, reflecting the fact that the most important competitive driver is the capacity to implement product innovations and to address particular demands of clients in specific market segments (see first two columns of table 16). Innovation capabilities are also the most important barrier to entry. Growing R\&D costs have led to the emergence of different forms of alliances among firms, mostly with the aim of diluting technological risks. These features mean that there is an important role for public or private research centres.

Due to the strategic role of innovation carriers, nations with complex industrial structures have always implemented active policies to promote and consolidate the competitiveness of these enterprises in local and international markets. In addition to support for technological development, import restrictions, favourable financing conditions, government purchasing power and fiscal incentives are frequently used mechanisms.

Of all industrial groups, Brazilian innovation carriers suffered the worst consequences of economic liberalization. Before this process, firms had reasonable levels of production capacity and well-qualified human resources, especially in mechanical engineering, as the result of a long learning process associated with an expanding local market and active industrial policies of the 1970s and 1980s. Even then, however, most producers of mechanical engineering and electronics-based equipment were not competitively strong, displaying high levels of verticalization and diversification, dependence on foreign technological suppliers, and merely incipient relations with the local scientific infrastructure.

In the course of the 1990s, producers of mechanical engineering and telecommunication equipments and computers shared a common feature: substantial strengthening of their production capabilities. However, this was not enough to resist foreign competitive pressures. New entrants from abroad acquired local firms, and intra-firm imports were extensively used (see last two columns of table 16). 
TABLE 16

Brazil: Patterns of competition (POC) and competitiveness in innovation carriers, then and now

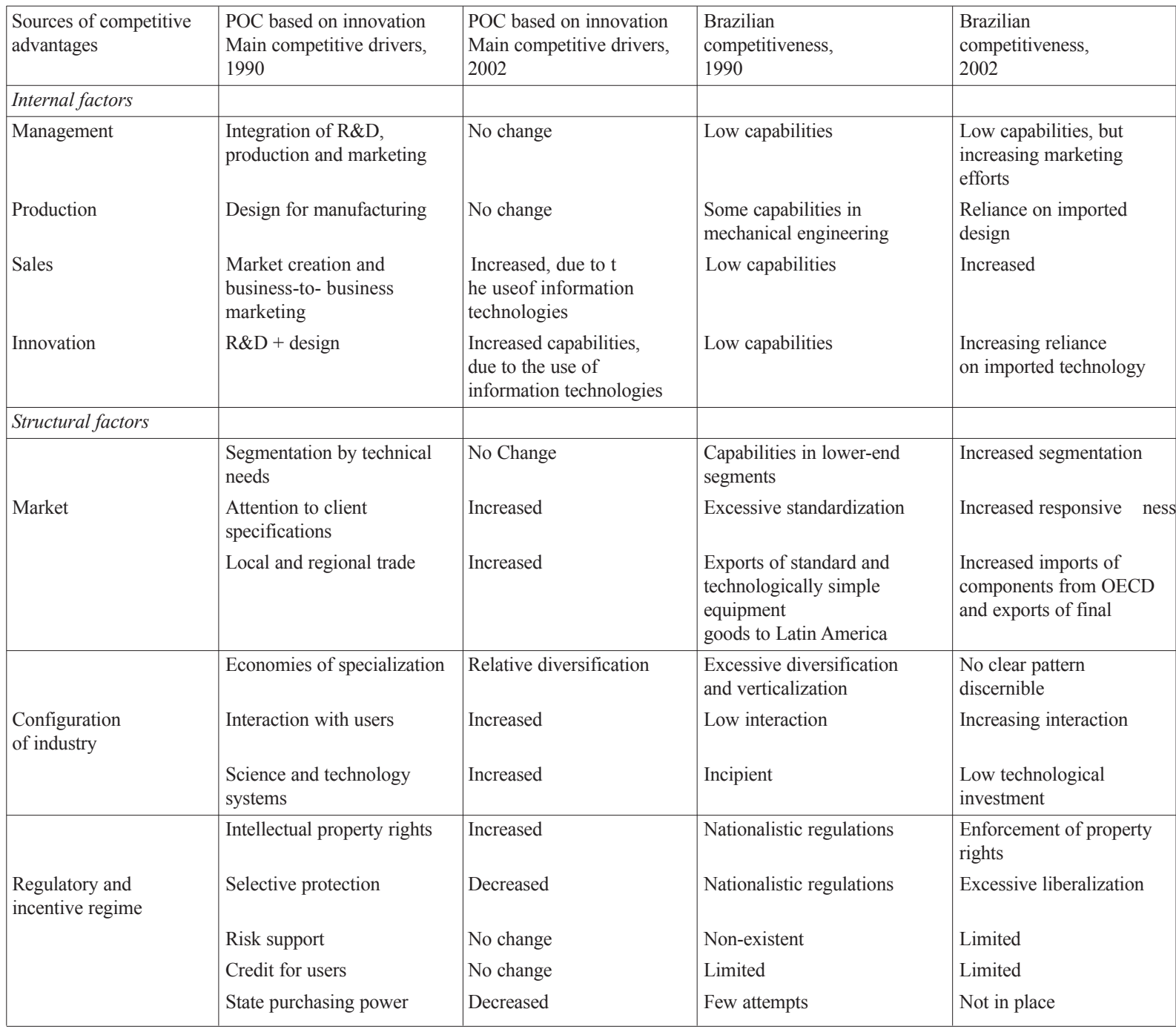

Source: Porto (2002).

2. Competitiveness in 2002: modernization, import dependence and ownership internationalization

\section{a) Growth, modernization, de-verticalization and product upgrading}

Suppliers of telecommunications equipment considerably expanded their production capacity due to the rigid expansion targets imposed upon telecommunication utilities during the privatization process.
Computer assembly became internationalized through foreign direct investment in new facilities and asset acquisition and substantial increases in imports of components, as a result of changes in legislation which equalized opportunities for local and foreign-owned firms, In the face of growing imports, producers of mechanical engineering-based goods promoted a rationalization process resulting in a significant decrease in production capacity. 
Corporate efforts were focused on the introduction of new organizational techniques to ensure greater efficiency of production processes, and reduction and specialization of product portfolio. Through the adoption of just-in-time methods and subcontracting, the mechanical engineering sector was able to improve efficiency and maintain minimum levels of production, with a negative impact on employment levels (which dropped from 331,900 in 1990 to 160,200 in 1999). In line with this trend, computer firms first of all outsourced administrative activities and subsequently introduced new organizational techniques that required fewer staff, resulting in sharp reductions in employment levels. Thus, after employment had expanded from 42,924 in 1984 to 74,155 in 1989 , by 1999 the total number of employees in the computer industry was down to 38,450 (Porto, 2002).

Low investment levels and trade liberalization significantly affected the producers of mechanical engineering equipment. While apparent consumption decreased from US\$ 17.2 billion in 1990 to US\$ 14.4 billion in 2000, imports increased and local production decreased substantially. During the decade, while production levels declined steadily, exports and imports evolved cyclically, with an upward trend until 1997 and declines thereafter (table 17).

TABLE 17

Brazil: production and international trade in mechanical equipment, 1990-2000 (US\$ billion)

\begin{tabular}{lcccccc}
\hline Year & Production & Exports & Imports & $\begin{array}{c}\text { Trade } \\
\text { balance }\end{array}$ & $\begin{array}{c}\text { Apparent } \\
\text { consumption }\end{array}$ & $\begin{array}{c}\text { Export } \\
\text { coefficient \% }\end{array}$ \\
\hline 1990 & 16.7 & 2.6 & 3.2 & -0.5 & 17.2 & 15.9 \\
1995 & 14.3 & 3.8 & 6.9 & -3.1 & 17.4 & 26.6 \\
2000 & 11.5 & 3.5 & 6.4 & -2.9 & 14.4 & 39.8 \\
\hline
\end{tabular}

Source: Vermulm and Erber (2002).

The scenario for suppliers of telecommunications equipment was very different from that of the mechanical engineering sector. In the second half of the 1990s, this industry faced expanding demand due to the rules on the privatization of telecommunications utilities, coupled with intensive technical progress. An estimate by Oliva (2002) suggests that under the investment-inductive rules of concessions, sales amounted to US\$ 20 billion between 1998 and 2000 .

Data from Oliva (2002) also show that sales revenue in 2000 was $124 \%$ higher than the 1995 level. These figures alone indicate that the growth in demand attracted firms to install new assembly units in the country. Brazilian firms were very efficient in setting up local facilities, relying strongly on global sourcing to ensure delivery times to clients. This is the reason why the industry's trade deficit reached US\$ 2 billion in 2001: the result of U\$ 3.5 billion of imports (43\% from the United States, 26\% from the European Union) and US\$ 1.5 billion of exports (90\% to Latin America).
With regard to the computer industry (computers and components), Porto (2002) found a big expansion in sales, from US\$ 6 billion in 1990 to US\$ 10.7 billion in 1998. Since then growth has slowed down. These figures suggest that the computer industry has managed to outgrow component production. To a large extent, this is explained by the increasing reliance of this industry on imported components.

Indeed, when contrasting imports of components and imports of final computer goods (table 18), the disparity is quite clear: from 1997 to 2001 the average annual value of components imports equalled US\$ 5.1 billion, while that of imported computers amounted to US\$ 1.02 billion. More important, when local computer sales decreased - after 2000 — and the Real was devalued — after 1999—, computer imports remained relatively stable but imports of electronic components increased even more. 
TABLE 18

Brazil: Computer industry imports and exports, 1997-2001

(US\$ million)

\begin{tabular}{|c|c|c|c|c|c|}
\hline Year & 1997 & 1998 & 1999 & 2000 & 2001 \\
\hline Exports $(1+2)$ & 1331 & 1458 & 1587 & 1865 & 1809 \\
\hline 1. Computers & 255 & 235 & 323 & 346 & 251 \\
\hline 2. Components & 1076 & 1223 & 1264 & 1519 & 1558 \\
\hline $\begin{array}{l}\text { of which, components } \\
\text { for computers }\end{array}$ & 91 & 124 & 151 & 144 & 146 \\
\hline Imports $(3+4)$ & 6406 & 5840 & 5874 & 7690 & 6793 \\
\hline 3. Computers & 1232 & 1090 & 855 & 1080 & 1032 \\
\hline 4. Components & 5174 & 4750 & 4839 & 6610 & 5761 \\
\hline $\begin{array}{l}\text { of which, components } \\
\text { for computers }\end{array}$ & 562 & 671 & 665 & 856 & 782 \\
\hline Trade balance & 5075 & 4382 & 4287 & 5825 & 4984 \\
\hline
\end{tabular}

Source: Porto (2002).

b) The division of labour between local and foreign-owned firms

The competitiveness of Brazilian mechanical engineering capital goods is higher in product lines of low and medium technological intensity, where product cycles have matured.

Price competitiveness is decisive, and company advantages lie in privileged access to low-cost inputs and labour. Brazilian industry is also competitive in specific market niches, especially where the equipment is technically more sophisticated, requiring strong interactions between suppliers and clients, and local and regional demand is relatively high in economic terms.

However, some of the structural features of the 1980s, especially the division of labour between local and foreign producers, have not changed. Locally owned companies are prevalent in low-technology segments, while foreign companies dominate sophisticated product lines. The companies that have managed to survive the hardships of the 1990s have improved their competitiveness: they are leaner in terms of production processes and product portfolios. Specialization levels have increased, and this may constitute the basis upon which to grow in the years to come. Even so, most of the competitive challenges of the early 1990s remain, especially those related to the continuing weakness of the technological capability base.

In telecommunications, despite the increasing reliance on imports, to a great extent demand could be supplied from local sources because of the industry's previous experience within Brazil. Most of the international players were already established in the country before economic liberalization, and some local firms were also very active, but the expansion of demand brought in new foreign firms, through the acquisition of local firms. As a result, in 2000 foreign companies controlled $91.3 \%$ of the US\$ 8.8 billion total sales of the sector in that year (Oliva, 2002).

Indeed, according to Porto (2002), when a broader definition is given to the computer and telecommunications industries, the picture does not change very much. The gross sales of the information technology industries increased from US\$ 16 billion to US\$ 30 billion between 1996 and 2000, with foreign-owned firms expanding their market share from $48.2 \%$ to $65.8 \%$, at the expense of locally-owned private firms. 
VIII

\section{After ten years of economic liberalization, rationalization and inward internationalization in Brazil: What comes next?}

The institutional transition towards a new "marketdriven" paradigm was not a smooth process and uncertainty increased, especially unpredictability in terms of the extent of entry of new competitors and imported goods. Firms lost the capacity to forecast the real size of their markets and reacted by undertaking defensive actions, most of them associated with cost reduction, production rationalization and product renewal, which led to further reductions of the already low levels of microeconomic confidence. These low levels of confidence were accompanied by a negative propensity to invest, with similarly negative repercussions on macroeconomic sustainability and economic growth.

A balance of the "Made in Brazil" production structure, ten years after economic liberalization, displays a strikingly different feature from those of other Latin American countries: between 1990 and 2002 very few genuinely new economic activities were added to the country's industrial matrix, and very few previously existing activities ceased to exist.

Most important changes were observed in the management of production processes and in the ownership landscape of industry. Modernization and inward internationalization were the most outstanding, economically significant and generalized processes taking place in Brazilian industry in the 1990-2002 period. These processes do not really represent innovation in the Schumpeterian sense. Foreign capital has always had a prominent role in industry, because the Brazilian economy was never closed to foreign ownership as it was in foreign trade. As for modernization, around the mid-1980s leading firms in most industrial sectors were already introducing updated organizational techniques to increase efficiency and quality (Ferraz, Kupfer and Haguenauer, 1996a).

Over the years, modernization and inward internationalization were strengthened among leading firms and extensively diffused across sectors, assuming economically significant proportions. The role of foreign capital was considerably strengthened, espe- cially in dynamic industrial segments. Modernization provided the basis upon which firms withstood competitive pressures from expanding imports and the entry of new competitors. The wide diffusion of labour-saving techniques and machinery, de-verticalization and subcontracting and the lack of sustained growth in demand levels caused a decline in employment never seen before in Brazilian history.

Modernization was strongly biased towards rationalization rather than towards expanding production capacity and developing innovation capabilities to support the introduction of new processes and products. Facing changing macroeconomic conditions, industrialists were not willing to invest in new plants and even less in R\&D, the most uncertain of all investments.

More interestingly, modernization did not induce changes in the relative position of firms. Those that were relatively stronger in the pre-change period have shown better adaptive capacity and vice-versa. Large firms and those which were foreign-owned, operating in the industrial commodities or durables sectors and located in the southern part of the country, have widened the relative gap separating them from firms lower down on the competitive ladder.

Foreign trade expanded significantly, from US\$ 50 billion in 1990 to US\$ 100 billion in 2001. But trade patterns remained relatively unchanged: imported goods had high income elasticity of demand, while low unit values prevailed in exports. Production modernization benefited from imported electronic components and chemical inputs, while the industrial commodities group still generates most of the country's foreign exchange. Trade deficits soared and were overcome only in 2000 , after a heavy currency devaluation. Regardless of these advances, the share of Brazilian foreign trade in world trade has declined from $1.4 \%$ in the mid-1980s to $0.75 \%$ in 2001 .

Mergers and acquisitions changed the ownership landscape of Brazilian industry, strongly reinforcing the share of foreign capital. Moreover, between 1990 
and 2002, investments in new plants and capacity expansion were carried out only in a very few sectors: steel, automotive products, consumer electronics and telecommunications equipment. These are examples of positive reactions to the expansion in demand and pro-active responses to increasing competition, and they are interesting in indicating a pro-growth vitality in Brazilian industry.

Among industrial groups, some interesting regularities exist. Strong competitiveness has been and remains essentially associated with commodity producers, where local capital is still prevalent. But commodity producers have followed a dual-track strategy: exports of low unit value products and internal sales of high unit value goods. In the durables sectors, competitiveness was strengthened - especially in middlerange products - through investments in new plants, increasing product differentiation and expanding imports of components. Foreign firms are dominant and exports are increasing. Heterogeneity is still an important feature of traditional industries, in which local capital mostly predominates. Responsiveness a key competitive driver — has increased, along with the formation of local production clusters and the relocation of plants to low-cost regions, especially the Northeast. Among innovation carriers, weaknesses still prevail, although the firms significantly improved their ability to deliver equipment when demand was expanding. Ownership internationalization has increased, inducing a marked division of labour: foreign firms control the assembly of equipment and the importation of strategic components, while locally owned firms are either suppliers of standardized components or producers of technologically simple machinery.

In short, Brazilian industry has shown considerable capacity to adapt to institutional change. Competitive capabilities were reinforced, thanks to a modernization drive strongly biased towards rationalization. Interestingly, however, in a few areas where growth prospects were high, industry responded by expanding capacity. Nevertheless, responsiveness to the challenges imposed by economic liberalization and growth prospects is unevenly distributed, favouring those firms with previously accumulated capabilities. Most probably this was an important factor in the acceleration of ownership internationalization.

Consequently, Brazil may face a development paradox in the years to come. History tells us that local capital and innovation capabilities have been outstanding features in countries which have been successful in sustaining economic development. If ownership internationalization is to remain and local innovation capabilities are to be promoted, then Brazilian private and public policy makers must seek new ways of attracting the necessary investments. To a great extent, this will mean an important departure from established policy practices, towards new ways of regulating and inducing firms to increase local value creation.

(Original: English)

Bibliography

Amadeo, E. and R.R. Soares (1996): Abertura, produtividade e organização industrial, Rio de Janeiro, International Centre for Education, Labour and Technology Transfer (CIET)/National Industrial Apprenticeship Service (SENAI), unpublished.

Bielschowsky, R. (1998): Investimentos na industria brasileira, 1995/97. Características e determinantes, Rio de Janeiro, National Confederation of Industry (CNI).

Bonelli, R. (1996): Produtividade industrial nos anos 90: controvérsias e quase-fatos, Economia brasileira em perspectiva, vol 2, Brasilia, Institute of Applied Economic Research (IPEA).

Costa, A.B. (2002): Estudo da competitividade de cadeias integradas: couro e calçados, Brasilia, Ministry of Development, Industry and Commerce (MDIC), unpublished.

Coutinho, L. and J.C. Ferraz (coords.) (1994): Estudo da competitividade da indústria brasileira, Campinas, Editora Papirus.

Ferraz, J.C., D. Kupfer and L. Haguenauer (1996a): The competitive challenge for Brazilian industry, CEPAL Review, No. 58, LC/G.1916-P, Santiago, Chile, April.

(1996b): Made in Brazil: desafios competitivos para a indústria brasileira, Rio de Janeiro, Campus.
Fonseca, M.G.D. (2002): Estudo da competitividade de cadeias integradas: papel e celulose, Brasilia, Ministry of Development, Industry and Commerce (MDIC), unpublished.

Gonzaga, G. (1996): Determinação do emprego industrial no Brasil, Rio de Janeiro, International Centre for Education, Labour and Technology Transfer (CIET)/ National Industrial Apprenticeship Service (SENAI), unpublished.

Hamaguchi, N. (2003): A Study on the Impact of Economic Liberalization in Brazil: 1995-2002, Las Series, No. 4, Tokyo, Japan External Trade Organization (JETRO), unpublished.

IBGE (Brazilian Geographical and Statistical Institute) (2000): Industrial Survey on Technological Innovation, Brasilia.

Neves, M.F. and M.K. Marino (2002): Estudo da competitividade de cadeias integradas: suco de laranja, Brasilia, Ministry of Development, Industry and Commerce (MDIC), unpublished.

Oliva, R. (2002): Estudo da competitividade de cadeias integradas: equipamentos de telecomunicações, Brasilia, Ministry of Development, Industry and Commerce (MDIC), unpublished.

Paula, G.M. (2002): Estudo da competitividade de cadeias integradas: siderurgia, Brasilia, Ministry of Development, 
Industry and Commerce (MDIC), unpublished.

Porto, J.R.D (2002): Estudo da competitividade de cadeias integradas: informática, Brasilia, Ministry of Development, Industry and Commerce (MDIC), unpublished.

Prochnik, V. (2002): Estudo da competitividade de cadeias integradas: têxtil e vestuário, Brasilia, Ministry of Development, Industry and Commerce (MDIC), unpublished.

Rocha, F. and D. Kupfer (2002): Structural changes and specialization in Brazilian industry: the evolution of leading companies and the M\&A process, The Developing Economies, vol. 3, No. 40, Tokyo, Institute of Developing Economies (IDE), December.
Sá, M.T.V.S (2002): Estudo da competitividade de cadeias integradas: eletrônica de consumo, Brasilia, Ministry of Development, Industry and Commerce (MDIC), unpublished. Sarti, F. (2002): Estudo da competitividade de cadeias integradas: automobilística, Brasilia, Ministry of Development, Industry and Commerce (MDIC), unpublished.

Vermulm, R. and F. Erber (2002): Estudo da competitividade de cadeias integradas: bens de capital mecânicos, Brasilia, Ministry of Development, Industry and Commerce (MDIC), unpublished. 